\title{
Construction of a 7-fold BAC library and cytogenetic mapping of 10 genes in the giant panda (Ailuropoda melanoleuca) Wei Liu $^{\dagger 1}$, Yonghui Zhao ${ }^{\dagger 1}$, Zhaoliang Liu1, Ying Zhang1, Zhengxing Lian ${ }^{2}$ and Ning Li*1
}

\author{
Address: ${ }^{1}$ State Key Laboratory for Agro-Biotechnology, China Agricultural University, Beijing 100094, China and ${ }^{2}$ College of Animal Science and \\ Technology, China Agricultural University, Beijing 100094, China \\ Email: Wei Liu - weiliucn04@hotmail.com; Yonghui Zhao - yonghuizhao@yahoo.com.cn; Zhaoliang Liu - liuzhaoliang@hotmail.com; \\ Ying Zhang - zhangying2113@163.com; Zhengxing Lian - zhxl@cau.edu.cn; Ning Li* - ninglbau@public3.bta.net.cn \\ * Corresponding author †Equal contributors
}

Published: 17 November 2006

BMC Genomics 2006, 7:294 doi:10.1186/147|-2164-7-294
Received: 01 August 2006

Accepted: 17 November 2006

This article is available from: http://www.biomedcentral.com/I47I-2/64/7/294

(C) 2006 Liu et al; licensee BioMed Central Ltd.

This is an Open Access article distributed under the terms of the Creative Commons Attribution License (http://creativecommons.org/licenses/by/2.0), which permits unrestricted use, distribution, and reproduction in any medium, provided the original work is properly cited.

\begin{abstract}
Background: The giant panda, one of the most primitive carnivores, is an endangered animal. Although it has been the subject of many interesting studies during recent years, little is known about its genome. In order to promote research on this genome, a bacterial artificial chromosome (BAC) library of the giant panda was constructed in this study.

Results: This BAC library contains 198,844 clones with an average insert size of $108 \mathrm{~kb}$, which represents approximately seven equivalents of the giant panda haploid genome. Screening the library with 15 genes and 8 microsatellite markers demonstrates that it is representative and has good genome coverage. Furthermore, ten BAC clones harbouring AGXT, GHR, FSHR, IRBP, SOXI4, TTR, BDNF, NT-4, LH and ZFXI were mapped to 8 pairs of giant panda chromosomes by fluorescence in situ hybridization (FISH).

Conclusion: This is the first large-insert genomic DNA library for the giant panda, and will contribute to understanding this endangered species in the areas of genome sequencing, physical mapping, gene cloning and comparative genomic studies. We also identified the physical locations of ten genes on their relative chromosomes by FISH, providing a preliminary framework for further development of a high resolution cytogenetic map of the giant panda.
\end{abstract}

\section{Background}

The giant panda is an endangered animal with a restricted habitat in South-western China. A survey revealed that only about 1,600 individuals remain in the wild [1]. The highly specialized reproductive behaviour [2] and low fertility make it difficult to increase their numbers quickly by breeding in captivity. In recent years, strenuous efforts have been made to protect this animal and considerable knowledge of its physiology, biochemistry, genetic diver- sity and ecology has been achieved, but research on the giant panda genome is still rare. So far only a few genes have been cloned and two have been mapped to specific giant panda chromosomes $[3,4]$.

A bacterial artificial chromosome (BAC) library is a powerful tool for studying genomes. Compared with yeast artificial chromosome (YAC) clones, BAC clones have many advantages such as high stability, easy manipula- 
tion and rare chimerism [5,6]. BAC libraries of human [7] and major livestock [8-11] have been constructed and widely used, but no such large-insert genomic DNA library has been reported to date for the giant panda.

We have constructed and characterized a seven-genome equivalent BAC library of the giant panda, and located ten genes to specific chromosomes by FISH using their BAC clones as probes.

\section{Results}

\section{BAC library construction}

The BAC library was constructed by cloning genomic DNA isolated from the white blood cells of a male giant panda, and partially digested with BamHI/HindIII, into the vector pBeloBAC11. It contains 198,844 clones, which were deposited in 518 384-well plates. Among these 198,844 clones, 145920 were from BamHI digestion and 52924 from HindIII digestion.

\section{Insert size distribution}

To evaluate the average size of inserted fragments in the library, DNAs were prepared from 261 randomly selected clones, cleaved with NotI and subjected to pulse-field gel electrophoresis with midrange PFG Marker II (New England Biolabs, USA). The insert size distribution is shown in Figure 1. The average insert size of these 261 clones is $108 \mathrm{~kb}$, indicating that the library represents a 7 -fold coverage of the giant panda haploid genome. Among the 261 clones, only 6 had no insert, suggesting that the percentage of non-recombination in the library is about $2.3 \%$. Approximately $53 \%$ of the clones contain inserts larger than $100 \mathrm{~kb}$.

\section{BAC library screening}

To assess the quality of this library further, 8 microsatellite markers were used for screening. The number of positive superpools varied from 1 to 10 with an average of 4.6 (Table 1). At the same time, 15 giant panda genes (ACTIVIN, AGXT, BDNF, FSH, FSHR, IRBP, GHR, GpH, GDNF, NT-4, LH, SOX14, TTR, ZFX1 and ZFX2) were also screened in the library using PCR. As shown in Table 2, the number of positive BAC clones varied from 2 to 8 with an average of 4.7. The actual number of clones obtained was slightly lower than was calculated theoretically, but at least 2 positive BACs for each of the genes were identified from the library.

\section{Gene mapping by FISH}

To estimate the fraction of chimeric clones in the BAC library, and furthermore to map some of the genes, a FISH approach was used. Ten BAC clones, containing AGXT, GHR, FSHR, IRBP, SOX14, TTR, BDNF, NT-4, LH and ZFX1 respectively, were mapped to 8 pairs of giant panda chromosomes. The specific locations of the 10 functional genes on the G-banded ideogram are listed in Figure 2. The band names of each chromosome are not given because no international standard karyotype has yet been established for the giant panda. The order of chromosomes was identified according to a previous study [12] by analyzing the size, G-band and centromere location. Fifteen metaphases were analyzed to map each gene.

\section{Discussion}

We have successfully constructed a giant panda BAC library, which is large-insert, deep-coverage and publicly available. One obstacle to genomic and molecular biology research on the giant panda is the difficulty of collecting samples. This BAC library will partially solve the problem.

BAC clones can be used as valuable probes for cytogenetic mapping by FISH. In this study, we successfully mapped 10 genes to giant panda chromosomes using their BAC clones as probes. Thus, the number of molecular markers on giant panda chromosomes could be increased to 12 . However, a major obstacle to this study in FISH mapping is the preparation of chromosome samples. Giant panda fibroblast cells cultured in our laboratory grew too slowly to provide sufficient high-quality chromosome samples. Therefore, only ten genes were mapped to chromosomes, though we had prepared for localizing fifteen genes by using the relative $\mathrm{BAC}$ clones.

The homologous relationship of chromosomes between human and giant panda has been established on the basis of comparative painting studies [13], so we deduced the approximate chromosome locations of the ten giant panda genes (Table 3 ) according to their human chromosome homologues [14]. Six genes, AGXT, GHR, FSHR, IRBP, SOX14 and TTR, were mapped to their expected chromosomes by FISH (Table 3), confirming the homologies of six pairs of chromosomes between giant panda and human, and identifying more precisely the regions of these chromosomes that are conserved between the two species.

The signals of the BAC clone harbouring ZFX1 were visualized both around the centromere of chromosome $X$ and at the terminal of chromosome Y. Since ZFX1 is located on chromosome $\mathrm{X}$ in almost all mammals, the specific signal at the terminal of chromosome $\mathrm{Y}$ may be because the $\mathrm{BAC}$ clone contains a fragment that is homologous between chromosomes $\mathrm{X}$ and $\mathrm{Y}$, or because it is a chimeric clone.

LH and NT-4 were both mapped on the same band of AME16q (Figures 2, 3), and these two genes are also close in the human genome (Table 3 ). This suggests that they belong to a conserved genome block. BDNF was mapped to chromosome 15q; its homologue in human is located 


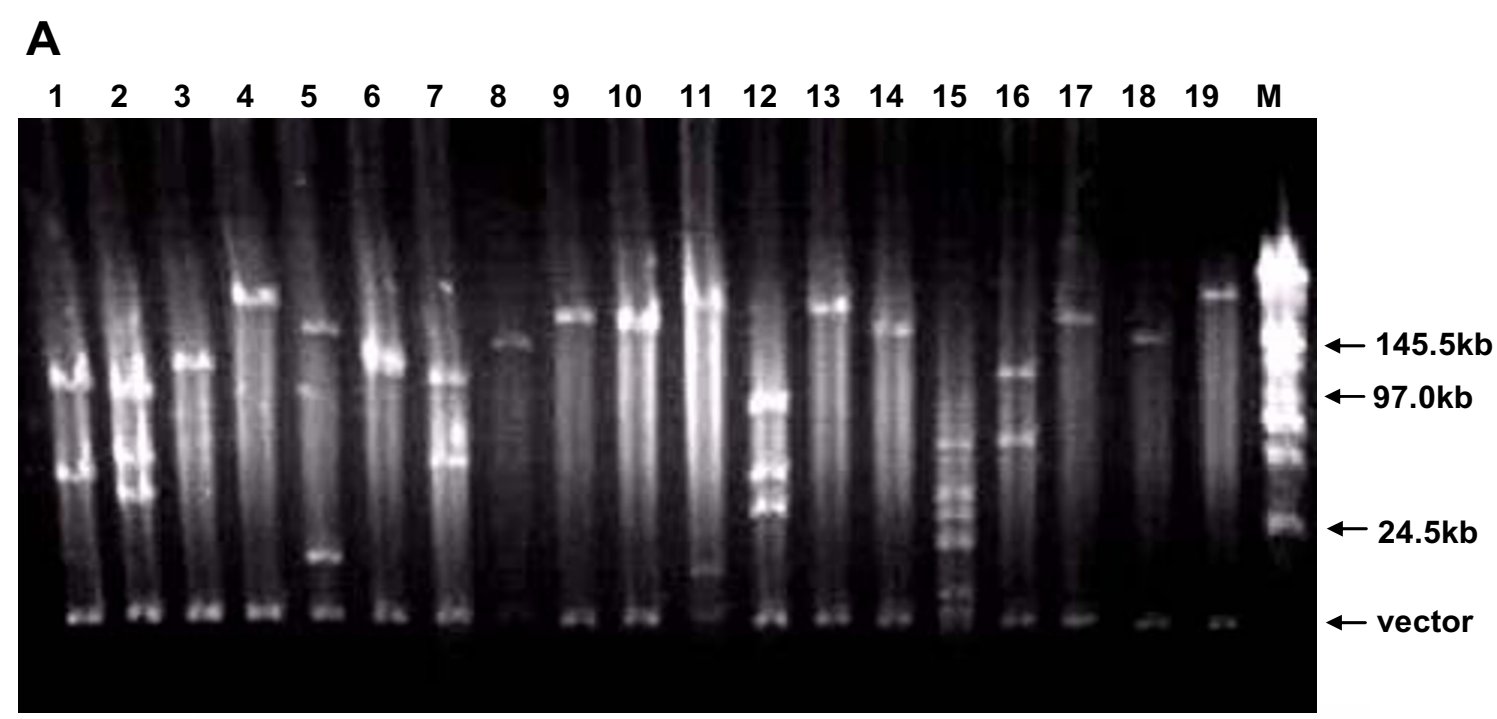

B

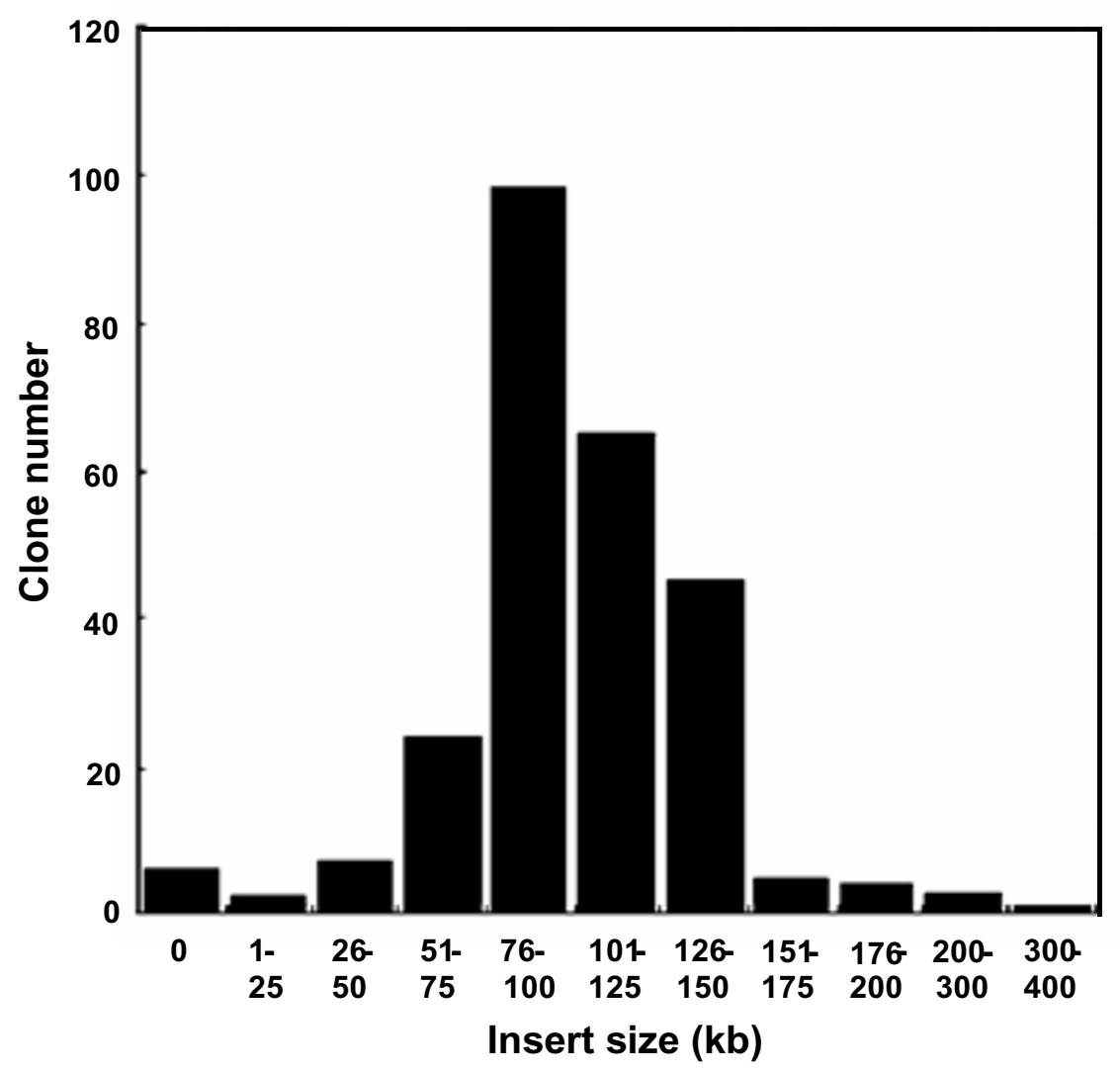

Figure I

Characterization of the giant panda BAC library. A. Analysis of the size of BAC clones by PFG electrophoresis. M: Mid range Marker II for PFGE (Bio-labs, New England). Lanes I-19: Notl digested DNA of randomly picked recombinant BAC clones. PFGE conditions were set with Bio-rad CHEF III: $6.0 \mathrm{v} / \mathrm{cm}$ for $12 \mathrm{~h}$, linear pulse time ramping from 0.1 to $40 \mathrm{~s}$. B. BAC insert size distribution in the library. Insert sizes were determined from $26 \mathrm{I}$ BAC clones. The horizontal axis shows the size range in $\mathrm{kb}$ while the vertical axis displays the number of clones corresponding to each size range. Insert sizes are reported in a cumulative histogram. 
Table I: Summary of screening results of the giant panda BAC library by PCR with primers for microsatellites

\begin{tabular}{|c|c|c|c|c|}
\hline Microsatellite Sequence Name & Primer $\left(5^{\prime}-3^{\prime}\right)$ & $\mathrm{T}_{\mathrm{a}}\left({ }^{\circ} \mathrm{C}\right)$ & Product length (bp) & Positive superpool number \\
\hline A204 & $\begin{array}{l}\text { F- CCTGCCCTATGGATTTCAGA } \\
\text { R-GGTCCATATCATGGTCTAAATGA }\end{array}$ & 63 & 321 & 10 \\
\hline A066 & $\begin{array}{l}\text { F- GATTATCCGTTGGCTTTGGA } \\
\text { R- CGTGGTTGTCTCCACACTTG }\end{array}$ & 60 & 337 & 3 \\
\hline B043 & $\begin{array}{l}\text { F- GACCCTGTGGCTCTGTGACT } \\
\text { R- GCGAGGGAAGGAAGAGAAAC }\end{array}$ & 60 & 310 & 6 \\
\hline GPMC-I & $\begin{array}{l}\text { F- AGAGAGAGAGCGAGCACGAG } \\
\text { R- AGCCACGAAACAGAGAGGAA }\end{array}$ & 63 & 207 & 1 \\
\hline GPMC-2I & $\begin{array}{l}\text { F- GAATGGTATGCCTGGGTGAC } \\
\text { R- AACACAAGCGGGGGAACT }\end{array}$ & 63 & 150 & 6 \\
\hline GPMC-40 & $\begin{array}{l}\text { F- TCCCTCAGCACCTTAACACC } \\
\text { R- TACTGGCCCAGGACACTAGC }\end{array}$ & 58 & 214 & 4 \\
\hline GPMC-52 & $\begin{array}{l}\text { F- CCGTCTCCAAGGTAACCTGA } \\
\text { R- AGAGATTGCTAGGCGGACAA }\end{array}$ & 60 & 190 & 3 \\
\hline GPMC-104 & $\begin{array}{l}\text { F- TCTCCATCAGGTTACCACTGC } \\
\text { R- CTGCGTGCCTCAGTCAGTTA }\end{array}$ & 60 & 261 & 4 \\
\hline
\end{tabular}

at chromosome 11p14.1, which indicates the conserved syntenic homology between AME15q and HSA11p. However, the mapping results for these three genes are not consistent with the giant panda-human comparative painting data (Table 3) owing to the problem of identifying chromosome order. In the giant panda, the sizes and morphologies of chromosomes 12 to 16 are so similar that the same chromosome has been designated different chromo-

Table 2: Summary of screening results of the giant panda BAC library by PCR with primers for functional genes

\begin{tabular}{|c|c|c|c|c|c|}
\hline Gene & Genebank accession No. & Primers $\left(5^{\prime}-3^{\prime}\right)$ & $\mathrm{T}_{\mathrm{a}}\left({ }^{\circ} \mathrm{C}\right)$ & PCR product size (bp) & Positive clone number \\
\hline ACTIVIN & AF350256 & $\begin{array}{l}\text { F- GGACATTGGCTGGAATGACT } \\
\text { R- GACATGGGTCTCAGCTTGGT }\end{array}$ & 54 & 207 & 4 \\
\hline$A G X T$ & A]539311 & $\begin{array}{l}\text { F- CTGTTTTTCATTGACTGGACTCTG } \\
\text { R- TCTCATCCATTATCTGGGGG }\end{array}$ & 58 & 539 & 4 \\
\hline GHR & $\underline{\mathrm{AF} 367203}$ & $\begin{array}{l}\text { F- CCTCTGGGGGAAAAAAAGTT } \\
\text { R- TCATCATCCTTTGCTCCAAG }\end{array}$ & 56 & 412 & 8 \\
\hline FSH & AF448454 & $\begin{array}{l}\text { F- TGTTGCTGGAGAGCAATCTG } \\
\text { R- TACGCCAGCTCTTTGAAGGT }\end{array}$ & 54 & 197 & 7 \\
\hline FSHR & $\underline{A F 415208}$ & $\begin{array}{l}\text { F- GCCAAAGGATTTGACACGAT } \\
\text { R- TGGTGACCAGGATCATCAGA }\end{array}$ & 56 & 202 & 6 \\
\hline GpH & $\underline{\text { AF448453 }}$ & $\begin{array}{l}\text { F- GCCCAGAATGCAAGCTAAAG } \\
\text { R- ACTGTGGCCTTGGTAAATGC }\end{array}$ & 54 & 190 & 5 \\
\hline soxI4 & $\underline{\mathrm{AFO} 16377}$ & $\begin{array}{l}\text { F- AACCCCAAGATGCACAACTC } \\
\text { R- ACGTAGCCTCTTGGCCTCAC }\end{array}$ & 54 & 108 & 6 \\
\hline IRBP & AY303836 & $\begin{array}{l}\text { F- CCAGGAAGTGGTGAGCAAGC } \\
\text { R- CGGTGAGGAAGAAGTCGGAC }\end{array}$ & 66 & 419 & 4 \\
\hline TTR & $\underline{\mathrm{AF} 039738}$ & $\begin{array}{l}\text { F- TCTGCAGAGCTCACTGAACC } \\
\text { R- TTCGATTAGCTGAGGGGAAA }\end{array}$ & 54 & 205 & 4 \\
\hline BDNF & $\underline{\mathrm{U} 56638}$ & $\begin{array}{l}\text { F- TCTGGAGAGCGTGAATGGG } \\
\text { R- CGATACAGGGACTTTTTCAAGG }\end{array}$ & 62 & 394 & 3 \\
\hline GDNF & AF516767 & $\begin{array}{l}\text { F- TGAAAAGGTCACCCGAGAAG } \\
\text { R- AGCCGCTGCAGTACCTAAAA }\end{array}$ & 54 & 219 & 5 \\
\hline NT-4 & AYI89135 & $\begin{array}{l}\text { F- AGCGAGACAGCACCAGCAA } \\
\text { R- TCAGACACCCAGTGCCTCC }\end{array}$ & 64 & 263 & 5 \\
\hline LH & $\underline{\mathrm{AF} 448455}$ & $\begin{array}{l}\text { F- GCTGTGGCTGCTGCTGAAC } \\
\text { R- CCACAGGGAAGGAGACCATG }\end{array}$ & 58 & 313 & 2 \\
\hline ZFXI & AF016379 & $\begin{array}{l}\text { F- TCGGTTCACACGAAGGACTAC } \\
\text { R- TGATACACCTTCCTGCCACTG }\end{array}$ & 59 & 284 & 4 \\
\hline ZFX2 & AFOI6380 & $\begin{array}{l}\text { F- GGTGCAGCAACATGCTCTTA } \\
\text { R- CCACGTGTTTCTTGAGTTCG }\end{array}$ & 54 & 188 & 4 \\
\hline
\end{tabular}




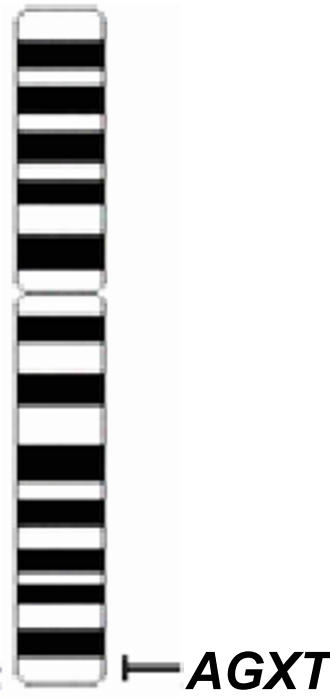

2

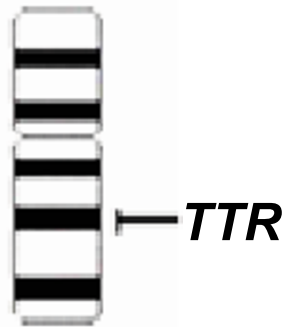

14

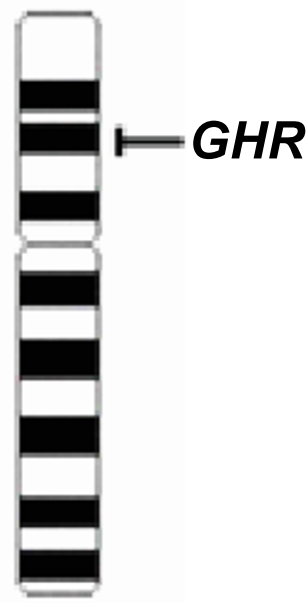

3

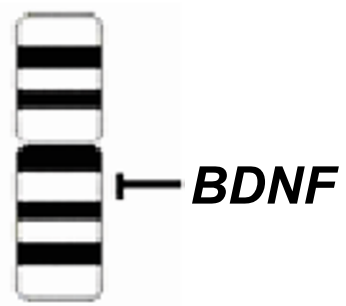

15

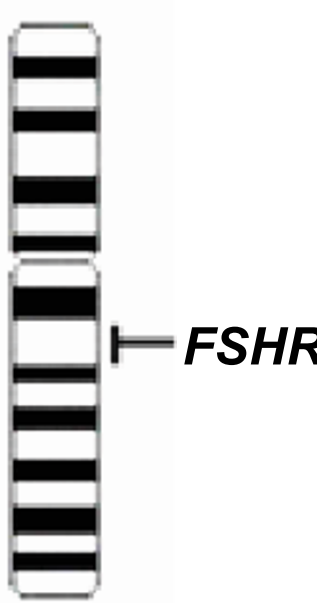

4

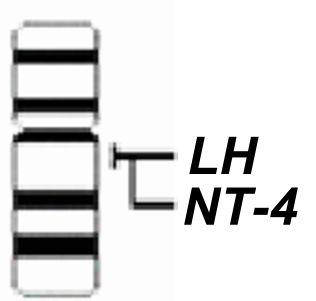

16

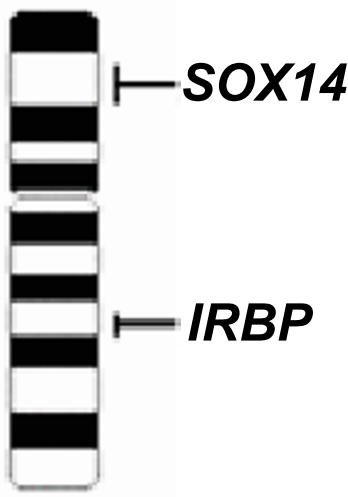

6

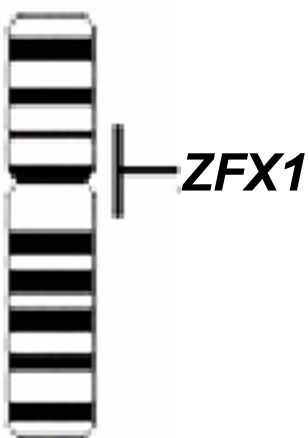

X

Figure 2

Physical locations of ten genes on G-banded ideogram of giant panda. The G-banded ideogram was drawn with software Video TesT-karyotype3.I (Video TesT Ltd, Russia, 2003). The names of the bands have not been listed because no international standard karyotype has yet been established for the giant panda.

some orders in different studies [12,13,15]. This problem will be solved when more markers are mapped to these chromosomes.

\section{Conclusion}

The first representative giant panda genomic BAC library has been constructed, covering about seven equivalents of the giant panda genome. This BAC library will serve as a valuable resource for genomic research on the endangered species. We also mapped 10 genes to their relative chromosomes by FISH using their BAC clones as probes, and this enriched the giant panda cytogentic map.

\section{Methods}

\section{Preparation of vector and HMW DNA}

The BAC vector pBeloBAC11 was purified by CsCl-ethidium bromide density gradient centrifugation, digested with the appropriate amount of HindIII or BamHI (New England Biolabs, USA) and treated with shrimp alkaline phosphatase (USB, USA). Linear vectors were recovered by electroelution as described by Osoegawa et al. [16]. A DNA plug was prepared as described by Birren et al. [17] from the white blood cells of a male giant panda and partially digested using 5 units of HindIII or BamHI per $\mu \mathrm{g}$ DNA at $37^{\circ} \mathrm{C}$ for $45 \mathrm{~min}$. Size-fractionation was per- 
Table 3: Chromosomal locations of ten genes in giant panda and of the homologous genes in human

\begin{tabular}{|c|c|c|c|c|}
\hline Gene & $\begin{array}{l}\text { Location in giant panda } \\
\text { chromosome (AME) }\end{array}$ & $\begin{array}{c}\text { Location in human chromosome } \\
\text { (HSA) }\end{array}$ & $\begin{array}{l}\text { Expected location in giant panda } \\
\text { chromosome (AME)* }\end{array}$ & Clone Address** \\
\hline$A G X T$ & $2 q$ & $2 q 37.3$ & 2 & 22IE23 \\
\hline GHR & $3 p$ & $5 p 12$ & 3 & 323D6 \\
\hline FSHR & $4 q$ & $2 p 16.3$ & 4 & $33 \mathrm{IF} 20$ \\
\hline sox 14 & $6 p$ & $3 q 22.3$ & 6 & I68E8 \\
\hline IRBP & $6 q$ & $10 q 11.22$ & 6 & $243 \mathrm{M} 3$ \\
\hline TTR & $14 q$ & $18 q \mid 2.1$ & 14 & $29 N 4$ \\
\hline BDNF & $15 q$ & | Ip|4.| & 16 & $212 \mathrm{~F} 3$ \\
\hline NT-4 & $16 q$ & $19 q 13.33$ & 12 & $229 L 4$ \\
\hline LH & $16 q$ & $19 q 13.33$ & 12 & $64 \mathrm{~A} 12$ \\
\hline ZFXI & $x$ & Xp22.II & $x$ & $403 N 3$ \\
\hline
\end{tabular}

* The expected chromosome locations of the ten genes in the giant panda according to human-giant panda comparison.

** BAC clone address for FISH mapping.

formed in a CHEF III apparatus (Bio-Rad, USA) and DNAs were separated in three stages as described by Osoegawa et al. [16]. DNA fragments with range of 150-250 kb were recovered by electroelution.

\section{Ligation and transformation}

At an approximately 1:10 molar ratio of insert: vector, 150 $\mathrm{kb}-250 \mathrm{~kb}$ DNA fragments were ligated to $30 \mathrm{ng}$ of linearized pBeloBAC11 vector in a $120 \mu$ total volume and incubated at $12{ }^{\circ} \mathrm{C}$ for $24-48 \mathrm{~h}$. The ligation mixture was then dialyzed on a microdialysis filter $(0.025 \mu \mathrm{m}$ pore size; Millipore) against $0.5 \times$ TE for $40 \mathrm{~min}$. Two microlitres of the ligation product was used to transform $20 \mu \mathrm{l}$ ElectroMAX DH10B competent cells (Gibico, USA) by electroporation on a Gene Pulser II (Bio-rad). The transformation parameters were as follows: resistance of pulse controller plus, $100 \Omega$; voltage gradient, $18 \mathrm{kv} / \mathrm{cm}$; capacitance, $25 \mu \mathrm{F}$. In total, 87 electroporations were performed to make the panda HindIII and BamHI library. Transformed cells were frozen at $-70^{\circ} \mathrm{C}$ prior to colony picking.

\section{Library pooling}

The frozen stocks of the primary clones were recovered and spread on large selection plates. Colonies with diameters $>1.5 \mathrm{~mm}$ were picked manually and incubated overnight at $37^{\circ} \mathrm{C}$ in 96 deep well plates containing LB medium supplemented with $10 \%$ glycerol and $12.5 \mu \mathrm{g} / \mathrm{ml}$ chloramphenicol. Using MultiPROBE ${ }^{\circledR}$ II automated liquid handling systems (PerkinElmer, USA), $80 \mu \mathrm{l}$ of cultures from four 96 plates were transferred to 384 well plates and stored at $-70^{\circ} \mathrm{C}$. To establish the two-step PCR screening systems, the library was divided into 26 superpools and one superpool comprised 20 384-well plates. Cultures from every superpool were combined to make superpool DNA for the first step PCR screening. In each superpool, cultures from each plate (384 clones), row (24 clones $\times 20$ plates $)$ and column ( 16 clones $\times 20$ plates $)$ were combined respectively to make DNA for the second step screening. The combined cultures were centrifuged and the bacterial pellet was suspended in TE then boiled in a microwave oven. After centrifugation, the supernatants containing the pooled DNA were transferred and stored in 96 well plates. The stock DNA was diluted 20 times to the working concentration for PCR screening.

\section{Estimation of average insert size}

Two hundred and sixty-one recombinant BAC clones were randomly picked and grown in LB medium overnight at $37^{\circ} \mathrm{C}$. DNA was prepared by alkaline lysis and digested with NotI, then separated by PFG electrophoresis. PFGE conditions were set with Bio-Rad CHEF III: $6.0 \mathrm{v} / \mathrm{cm}$ for $12 \mathrm{~h}$, linear pulse time ramping from 0.1 to $40 \mathrm{~s}$.

\section{BAC library screening}

Primers for each gene and some microsatellite markers were designed according to the giant panda DNA sequences published in NCBI, and the other microsatellite markers were designed according to the sequences from our laboratory (A204, A066 and B043). BAC screening was performed by two-step PCR (superpools PCR and 4DPCR) [see Additional file 1]. Positive BAC clones were confirmed by sequencing of PCR products.

\section{Fluorescence in situ hybridization}

For FISH analysis, chromosomes were prepared from a male giant panda fibroblast using a standard cytogenetic protocol. The FISH method was modified from the previous study [18]. Briefly, chromosomes were performed Gbands and well-banded metaphases were photographed. The BAC clones of 10 functional genes (Table 3) were used as probes and were labelled by nick translation with biotin-14-dATP (Invitrogen, Carlsbad, CA92008, USA). The denatured probes were dissolved in hybridization solution to a final concentration of $50 \mathrm{ng} / \mu \mathrm{l}$ and prehybridized for $40 \mathrm{~min}$ at $37^{\circ} \mathrm{C}$. Hybridization was performed for 17 hours at $37^{\circ} \mathrm{C}$ in a humid chamber. Probes were detected with FITC-conjugated avidin (Vector, Burlingame, CA94010, USA) and signals were amplified by 


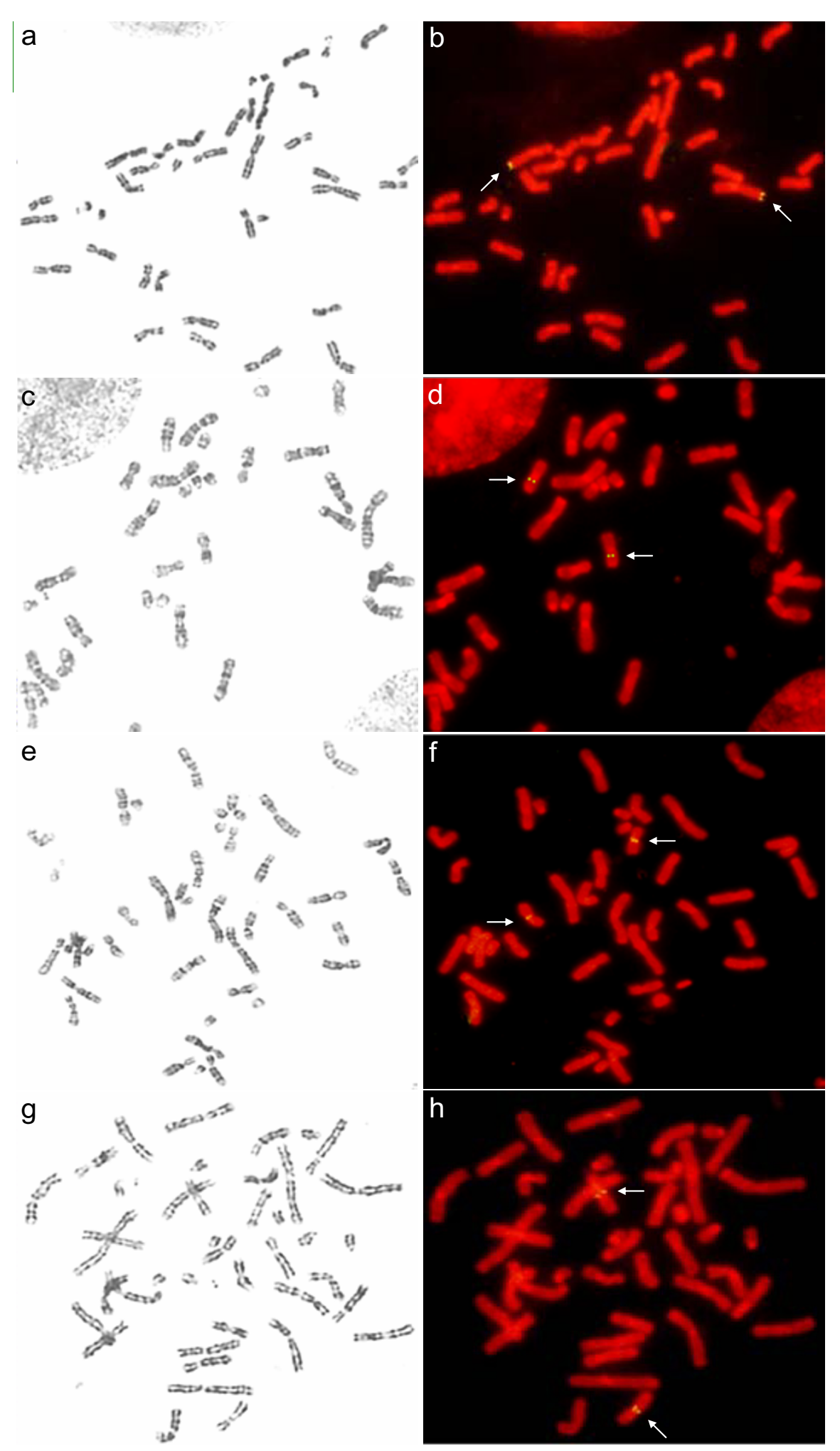

Figure 3

Representative scheme of chromosome locations of AGXT (a+b), BDNF (c+d), LH (e+f), and NT-4 (g+h) in giant panda identified by FISH. a, c, e, g show G-banded metaphase chromosomes spread before FISH; b, d, f, h show the same chromosomes spread after FISH. Arrow shows the specific signals. 
biotinylated anti-avidin (Vector). Chromosomes were counterstained with $0.5 \mu \mathrm{g} / \mathrm{ml}$ propidium iodide. Images were obtained with an epifluorescence microscope equipped with a DP70 CCD camera (Olympus, Japan). Gbanded ideograms were drawn with Video TesTkaryotype3.1 software (Video TesT Ltd, Russia, 2003).

\section{Authors' contributions}

WL constructed the BAC library and drafted the manuscript with YHZ, ZLL and NL. YHZ participated in the gene screening and FISH mapping. ZLL and YZ contributed to the BAC library pooling and screening. ZXL and NL conceived the project and supervised its execution. All authors read and approved the final manuscript.

\section{Additional material}

\section{Additional File 1}

Scheme representations of BAC library and PCR screening systems. Detailed method of two-step screening of the BAC library (superpools PCR and $4 D-P C R$ ) is shown.

Click here for file

[http://www.biomedcentral.com/content/supplementary/14712164-7-294-S1.pdf]

\section{Acknowledgements}

The authors thank Dr. Yuhui Peng in Beijing Zoo for providing the giant panda blood samples and Dr. Qiuzhen Pan for providing the giant panda fibroblast cells. This work was supported by the National Basic Research Program of China, the Natural Scientific Foundation of China and the Beijing Science and Technology Committee.

\section{References}

I. World Wildlife Fund [http://www.worldwildlife.org/pandas/]

2. Kleiman DG: Ethology and reproduction of captive giant pandas (Ailuropoda melanoleuca). Z Tierpsychol 1983, 62:1-46.

3. Liu XH, Zhao YH, Zhang YH, Liu W, Li N: Cloning and mapping MCIR to chromosome 16 in giant panda. Animal Genetics 2005, 36:280-28I.

4. Zeng CJ, Yu JQ, Pan HJ, Wan QH, Fang SG: Assignment of the giant panda MHC class II gene cluster to chromosome $9 q$ by fluorescence in situ hybridization. Cytogenet Genome Res 2005, 109:533.

5. Shizuya H, Birren B, Kim UJ, Mancino V, Slepak T, Tachiiri Y, Simon $\mathrm{M}$ : Cloning and stable maintenance of 300-kilobase-pair fragments of human DNA in Escherichia coli using an F-factorbased vector. Proc Natl Acad Sci USA 1992, 89:8794-8797.

6. Gill CA, Davis SK, Taylor JF, Cockett NE, Bottema CD: Construction and characterization of an ovine bacterial artificial chromosome library. Mammalian Genome 1999, 10: I 108-I III.

7. Kim UJ, Birren BW, Slepak T, Mancino V, Boysen C, Kang HL, Simon $\mathrm{MI}$, Shizuya $\mathrm{H}$ : Construction and characterization of a human bacterial artificial chromosome library. Genomics 1996, 34:2/3-2|8.

8. Cai L, Taylor JF, Wing RA, Gallagher DS, Woo SS, Davis SK: Construction and characterization of a bovine bacterial artificial chromosome library. Genomics 1995, 29:4 I3-425.

9. Rogel-Gaillard C, Bourgeaux N, Billault A, Vaiman M, Chardon P: Construction of a swine BAC library: application to the characterization and mapping of porcine type $C$ endoviral elements. Cytogenet Cell Genet 1999, 85:205-2 II.
10. Vaiman D, Billault A, Tabet-Aoul K, Schibler L, Vilette D, OustryVaiman A, Soravito C, Cribiu EP: Construction and characterization of a sheep BAC library of three genome equivalents. Mamm Genome 1999, 10:585-587.

II. Liu H, Liu K, Wang J, Ma RZ: A BAC clone-based physical map of ovine major histocompatibility complex. Genomics 2006, 88:88-95.

12. Nash WG, O'Brein SJ: A comparative chromosome banding analysis of the Ursidae and their relationship to other carnivores. Cytogenet Cell Genet 1987, 45:206-2I2

13. Nash WG, Wienberg J, Ferguson-Smith MA, Menninger JC, O'Brien S): Comparative genomics: tracking chromosome evolution in the family Ursidae using reciprocal chromosome painting. Cytogenet Cell Genet 1998, 83:182-192.

14. Ensembl Human [http://www.ensembl.org/Homo sapiens/ index.html]

15. Wurster-Hill DH, Bush M: The interrelationship of chromosome banding patterns in the giant panda (Ailuropoda melanoleuca), hybrid bear (Ursus middendorfi $\times$ Thalarctos maritimus), and other carnivores. Cytogenet Cell Genet 1980, 27:147-154.

16. Osoegawa K, Woon PY, Zhao B, Frengen B, Tateno M, Catanese JJ, de Jong PJ: An improved approach for construction of bacteria artificial chromosome libraries. Genomics 1998, 52: I-8.

17. Birren B, Green ED, Klapholz S, Myers RM, Roskams J: Preparation, manipulation, and mapping of HMW DNA. In Genome Analysis: A Laboratory Manual Volume I. Cold Spring Harbor: Cold Spring Harbor Laboratory Press; 1997:91-103.

18. Coppieters W, Zijlstra C, Van de Weghe A, Bosma AA, Peelman L, van Zeveren $A$, Bouquet $Y$ : A porcine minisatellite located on chromosome 14q29. Mammal Genome 1994, 5:591-593.
Publish with Biomed Central and every scientist can read your work free of charge

"BioMed Central will be the most significant development for disseminating the results of biomedical research in our lifetime. "

Sir Paul Nurse, Cancer Research UK

Your research papers will be:

- available free of charge to the entire biomedical community

- peer reviewed and published immediately upon acceptance

- cited in PubMed and archived on PubMed Central

- yours - you keep the copyright
BioMedcentral 